\title{
Inter-annual climate variability affects foraging behavior and nutritional state of thick-billed murres breeding in the southeastern Bering Sea
}

\author{
N. Kokubun ${ }^{1,2}$, A. Takahashi ${ }^{1,2, *}$, R. Paredes ${ }^{3}$, R. C. Young ${ }^{4,5}$, N. N. Sato ${ }^{2}$, \\ T. Yamamoto ${ }^{1,6,7}$, D. M. Kikuchi' ${ }^{2}$, E. V. Kitaiskaia ${ }^{4}$, M. Ito ${ }^{1,6,8}$, Y. Watanuki ${ }^{6}$, A. P. Will ${ }^{1,4}$, \\ R. Lauth ${ }^{9}$, M. D. Romano ${ }^{10}$, A. S. Kitaysky ${ }^{4}$ \\ ${ }^{1}$ National Institute of Polar Research Japan, Tachikawa, Tokyo 190-8518, Japan \\ ${ }^{2}$ Department of Polar Science, SOKENDAI (The Graduate University for Advanced Studies), Tachikawa, Tokyo 190-8518, Japan \\ ${ }^{3}$ Department of Fisheries and Wildlife, Oregon State University, Corvallis, OR 97331-3803, USA \\ ${ }^{4}$ Department of Biology and Wildlife, Institute of Arctic Biology, University of Alaska Fairbanks, Fairbanks, AK 99775-7000, USA \\ ${ }^{5}$ Instituto de Ecología, Universidad Nacional Autónoma de México, Circuito Exterior S/N anexo Jardín Botánico exterior, \\ Ciudad Universitaria, Ciudad de México, CP 04500, Mexico \\ ${ }^{6}$ Graduate School of Fisheries Science, Hokkaido University, Hakodate, Hokkaido 040-0821, Japan \\ ${ }^{7}$ Graduate School of Environmental Studies, Nagoya University, Nagoya, Aichi 464-8601, Japan \\ ${ }^{8}$ Department of Applied Biosciences, Faculty of Life Sciences, Toyo University, Itakura, Gunma 374-0193, Japan \\ ${ }^{9}$ NOAA Fisheries, Alaska Fisheries Science Center, Seattle, WA 98115-0070, USA \\ ${ }^{10}$ Alaska Maritime National Wildlife Refuge, US Fish and Wildlife Service, Homer, AK 99603, USA
}

\begin{abstract}
Warm oceanographic conditions of the continental shelf regions in the southeastern Bering Sea are associated with drastic increases in the abundance of juvenile walleye pollock Gadus chalcogrammus at shallow depths. We hypothesized that thick-billed murres Uria lomvia would benefit from these warm conditions by taking advantage of such an abundant prey resource available near their breeding colonies. We compiled a large dataset on the foraging behavior and nutritional state of murres breeding on St. George Island between 2003 and 2015. Murres foraged mostly on the continental shelf in warm years, but foraged in both on-shelf and off-shelf habitats in cold years. Shifts in foraging locations were associated with changes in diving depths. Nighttime foraging and daily diving effort increased during cold years, suggesting murres had to work more to obtain food under cold compared to warm conditions. Chick diets shifted from squid and benthic fishes in cold years to juvenile pollock in warm years. Foraging trip duration and reproductive success of birds were not affected by shifting oceanographic conditions, suggesting that murres behaviorally mediated the effects of inter-annual climate variability on their reproduction. However, this 'behavioral buffering' had associated costs, reflected in higher corticosterone concentrations in the blood of murres in cold compared to warm years, indicating that breeding birds incurred higher levels of nutritional stress under cold conditions. Our multiyear integrative study provides support that warmer conditions on the continental shelf might benefit piscivorous seabirds due to an increase in the availability of juvenile walleye pollock in the southeastern Bering Sea.
\end{abstract}

KEY WORDS: Seabirds · Behavioral plasticity · Diving · GPS tracking · Nutritional stress · Corticosterone

${ }^{*}$ Corresponding author: atak@nipr.ac.jp

${ }^{\S}$ Advance View was available online January 29, 2018
(C) The authors 2018. Open Access under Creative Commons by Attribution Licence. Use, distribution and reproduction are unrestricted. Authors and original publication must be credited. 


\section{INTRODUCTION}

Climate impacts on seabirds have been documented worldwide (reviewed in Sydeman et al. 2012, Jenouvrier 2013). The effect of climate change on seabirds can be positive, negative, or neutral, and responses may be non-linear, often involving complex species- and/or region- specific ecological processes (Sydeman et al. 2012). Seabird foraging behavior is considered to be the most sensitive parameter to changes in food availability, and seabirds may buffer the effects of environmental changes by changing diet and at-sea foraging behavior (e.g. Cairns 1987, Piatt et al. 2007, Grémillet et al. 2012). Long-term variability in seabird foraging behavior could provide vital information on the ecological processes affecting them under changing ocean conditions. However, only a few studies have reported foraging responses of seabirds in relation to long-term inter-annual changes in ocean climate conditions (Weimerskirch et al. 2012, Bost et al. 2015).

The southeastern Bering Sea is one of the most productive regions in the world (Aydin \& Mueter 2007), providing important foraging habitat for a variety of marine predators, including seabirds. In recent decades, this region has experienced a series of cold and warm regimes which have affected the biomass and distribution of plankton and nekton communities (Coyle et al. 2011, Hunt et al. 2011, Eisner et al. 2014). One of the dominant environmental features that has a profound influence on the ecological conditions of the continental shelf of the southeastern Bering Sea is the bottom temperature during summer (Wyllie-Echeverria \& Wooster 1998). Extensive winter sea-ice cover usually contributes to the formation and extension of cold bottom water, the 'cold pool' (temperature $<2^{\circ} \mathrm{C}$ ), over the continental shelf in the following summer (Stabeno et al. 2012). In cold summers, the distribution of fish species that are associated with cold bottom temperatures such as capelin Mallotus villosus or Arctic cod Boreogadus saida shift southward (Brodeur et al. 1999, Mueter \& Litzow 2008, Hollowed et al. 2012). On the other hand, in warm summers, the distribution of warm-water fishes such as age-0 walleye pollock Gadus chalcogrammus shifts northward over the continental shelf (WyllieEcheverria \& Wooster 1998, Brodeur et al. 1999, Siddon et al. 2013). Walleye pollock are an important prey for higher trophic level predators in the Bering Sea (Sinclair et al. 2008). Recent studies have shown that age-0 pollock have 51 times higher near-surface densities when sea ice retreats early (typically warm) compared to years when sea ice retreats late (typi- cally cold years) (Renner et al. 2016, Hunt et al. 2018, this Theme Section). Shifting temperature regimes also affect the quality of prey available to seabirds, as age-0 pollock are $33 \%$ higher in energy density during cold years than in warm years (Heintz et al. 2013). Whether such a high abundance of lower quality age-0 pollock available on the shelf in warm years offers favorable foraging conditions for piscivorous seabirds breeding in the region is not well known (but see Satterthwaite et al. 2012).

Thick-billed murres Uria lomvia (hereafter referred to as 'murres') are pursuit diving seabirds abundant in the Bering Sea, with a large breeding colony located at St. George Island, Pribilof Islands. Murres might be sensitive to changes in the availability of forage fish near their breeding colonies due to high energetic costs of flight (Elliott et al. 2013). Changes in prey species delivered by parent murres to feed their chicks reflect changes in the abundance of forage fish and invertebrates near the breeding colonies (Gaston et al. 2003). On the Pribilof Islands, pollock and squid have been recorded as the major prey species in chick diets, though the relationship between diet composition and environmental parameters is unclear (Renner et al. 2012). Previous studies on foraging locations showed that during cold years, murres fed in both the nearby on-shelf and distant offshelf (located $>30 \mathrm{~km}$ away from St. George Island) habitats, and squid appeared to dominate their diet (Harding et al. 2013, Paredes et al. 2015). It is currently unknown if during warm years, murres would concentrate their foraging efforts on the abundant age- 0 pollock in the continental shelf region near the breeding colony. Alternatively, since age-0 pollock are relatively low in energy content in warm years (Heintz et al. 2013), murres may continue feeding on higher quality prey at the distant off-shelf habitats as they do during cold years (Harding et al. 2013, Paredes et al. 2015). Therefore, a study on inter-annual changes in foraging locations, diet, and associated changes in diving behavior is needed to examine how murres respond to oscillating warm and cold oceanographic conditions in the southeastern Bering Sea.

Changes in foraging behavior and diet may result in changes in energy expenditures (Kitaysky et al. 2000, Welcker et al. 2015), which in turn may affect the homeostasis, reproductive success or survival of parent birds. In seabirds, concentrations of the adrenocortical hormone corticosterone in blood plasma have been shown to increase with a decline in food availability (Kitaysky et al. 1999, Riechert et al. 2014, Barrett et al. 2015, reviewed in Sorenson et 
al. 2017) and are negatively correlated with reproductive performance (Kitaysky et al. 2007, 2010, Satterthwaite et al. 2012) and adult survival (Kitaysky et al. 2007, 2010, Satterthwaite et al. 2010). We used this measure to determine whether changes in foraging behavior are coming at a cost to adult seabirds, and examined whether warm or cold ocean conditions impose different levels of nutritional stress on thick-billed murres. Previous long-term studies have suggested that warming conditions might be beneficial (reflected in low levels of nutritional stress as measured by baseline corticosterone) for blacklegged kittiwakes Rissa tridactyla, surface-feeding piscivorous seabirds that also breed on the Pribilof Islands (Satterthwaite et al. 2012). Whether this pattern might also apply to thick-billed murres (Benowitz-Fredericks et al. 2008, Yamamoto et al. 2016), which have access to prey at depth, has not yet been examined in the context of long-term interannual variability in oceanographic conditions.

In this study, we examined the foraging and physiological responses of thick-billed murres to ocean climate conditions in the southeastern Bering Sea. We hypothesized that (1) if pollock is abundant on the continental shelf during warm years, murres will concentrate their foraging efforts on this region, and their diet and diving behavior will reflect associated changes compared to cold years, and (2) if warming conditions are beneficial for murres, lower nutritional stress will be expected given the favorable conditions both in abundance and proximity of pollock to the breeding colony. We tested these hypotheses by compiling data on at-sea foraging behavior and chick diet collected across $9 \mathrm{yr}$ and baseline corticosterone across 10 yr (2003 to 2015), and by examining their relationships to inter-annual variability in summer bottom temperature.

\section{MATERIALS AND METHODS}

\section{Study site}

The field study was conducted on St. George Island, Pribilof Islands, a part of the Alaska Maritime National Wildlife Refuge, during late July to early August 2003 to 2015. The study sites on the island varied between years: we studied on both the northern (Village Cove: $56^{\circ} 36^{\prime} \mathrm{N}, 169^{\circ} 33^{\prime} \mathrm{W}$ ) and southern (Zapadni Bay: $56^{\circ} 35^{\prime} \mathrm{N}, 169^{\circ} 41^{\prime} \mathrm{W}$ and Red Bluffs: $56^{\circ} 33^{\prime} \mathrm{N}, 169^{\circ} 40^{\prime} \mathrm{W}$ ) coasts of the island in 2008, 2009, and 2010, and only on the northern coast (High Bluffs: $56^{\circ} 36^{\prime} \mathrm{N}, 169^{\circ} 39^{\prime} \mathrm{W}$ ) in other years.

\section{Data availability}

The type of available data on behavioral and physiological parameters varied between years (detailed in Tables S1 \& S2 in the Supplement at www. int-res.com/articles/suppl/m593p195_supp.pdf). We obtained data on foraging locations with GPS data loggers for 6 yr during 2008 to 2015, diving behavior with time-depth recorders (TDRs) or accelerometers for $9 \mathrm{yr}$ during 2004 to 2015, and chick diet for $9 \mathrm{yr}$ during 2004 to 2015 (detailed in Table S3). We obtained blood samples and measured baseline corticosterone levels of chick-rearing birds for $10 \mathrm{yr}$ during 2003 to 2015 (from birds with and without data loggers; see Table S4). Our dataset included previously reported data on foraging locations (Paredes et al. 2015, Yamamoto et al. 2016), diving behavior and chick diet (Takahashi et al. 2008, Ito et al. 2010, Kokubun et al. 2010b, 2016, Paredes et al. 2015, Young et al. 2015), and baseline corticosterone (Benowitz-Fredericks et al. 2008, Paredes et al. 2015, Yamamoto et al. 2016, Young et al. 2016).

\section{Data logger deployment and recovery}

We captured birds attending their chicks with a 5 to $8 \mathrm{~m}$ noose pole. We deployed data loggers on the back (in case of GPS and some accelerometers), on the belly (most accelerometers and TDRs), or on the leg with a plastic ring (TDRs with GPS loggers). The loggers that were attached to the back or belly feathers were secured with strips of Tesa ${ }^{\circledR}$ tape and cyanoacrylate glue (Loctite ${ }^{\circledR}$ 401). Birds were handled for less than $20 \mathrm{~min}$. The birds were recaptured between 1 to $6 \mathrm{~d}$ after the logger deployment (overall recovery rate: $73.5 \%$; Table $\mathrm{S} 2$ ); the loggers were then removed and the data downloaded to a computer. We sampled blood to determine sex (following Griffiths et al. 1998) and measure baseline plasma corticosterone levels (see below).

\section{Foraging location and distance}

We used several types of GPS loggers to obtain data on foraging locations: GiPSy2, GiPSy4 (TechnoSmart), or CatTraQ (Catnip Technologies; Table S2). The loggers were set to record locations every 1 to $2 \mathrm{~s}, 1 \mathrm{~min}$ (for 2008 to 2010), or at the rate of 0.5 to 5 fixes $\mathrm{min}^{-1}$ (for 2013 to 2015). GPS positions were resampled every $1 \mathrm{~min}$ if the data were obtained more frequently, and the last location just prior to a 
dive was used as the location of the dive. The GPS loggers sometimes failed positioning continuously. In these cases, the locations of dives were interpolated linearly using nearest neighbor locations associated with the times when the dives occurred (Kokubun et al. 2010a). If GPS loggers failed positioning continuously for more than $4 \mathrm{~h}$, we regarded the dive locations as unknown during these periods. We calculated the maximum distance from the colony (straight line distance between the nest site and most distant trip location) for each trip. We also recorded the latitude of the most distant GPS locations from the colony ('trip latitude'), and examined annual differences in trip latitude.

\section{Foraging trip duration}

We calculated foraging trip durations of birds carrying accelerometers, TDRs, or GPS loggers. For accelerometer birds, acceleration data were filtered to visualize the body angle and body movement, and then were used to determine the periods of colony attendance and foraging trips (see Takahashi et al. 2008). For TDR birds, temperature records were used to determine departure from and arrival to the colony (Ito et al. 2010). For GPS birds, the start of a foraging trip was defined when a bird was $500 \mathrm{~m}$ from the nest, and was often supported by temperature readings from the concurrently attached TDRs. We categorized foraging trips that crossed local midnight as overnight foraging trips, and all other trips that did not cross local midnight as day foraging trips (Harding et al. 2013, Paredes et al. 2015).

\section{Diving behavior}

We used several types of accelerometers and TDRs to obtain data on diving behavior: UME-D2GT, ORID3GT (Little Leonardo), Axy-Depth (TechnoSmart), Cefas-G5 (CEFAS Technology), and LAT1500, LAT2500 (Lotek Wireless) (Table S2). The sampling interval and depth threshold to start recording varied among study years (Table S2). For the entire dataset, we considered dives only when depth readings reached deeper than $5 \mathrm{~m}$. First, this reduces noise due to bird's activities at the sea surface, such as bathing or avoiding waves. Second, only diving depths deeper than $5 \mathrm{~m}$ were recorded for 12 birds in 2008 and 2009 (Table S2). The statistical results, and thus our conclusion, remained the same when we removed these 12 birds and used the depth readings deeper than $1 \mathrm{~m}$.
We categorized dives into day or night dives based on local sunset (23:00 to 23:40 h) and sunrise times (07:10 to $07: 50 \mathrm{~h}$ ) calculated for each day of the study period, available from the Hydrographic and Oceanographic Department of Japan Coast Guard (www1.kaiho.mlit.go.jp/KOHO/automail/sun_form3.h $\mathrm{tml})$. We then calculated the proportion of night dives to total number of dives for each bird. We also calculated mean dive depth during nighttime and during the midday period (defined as a $6 \mathrm{~h}$ period spanning local midday), and total dive time (sum of dive durations) per day during the deployment periods.

\section{Chick diet}

Chick diet was recorded each year from the visual observations of prey items carried by adults to their chicks. Visual observations were made colony-wide, not only for adults with data loggers. Prey items were visually identified to the lowest taxonomic level possible during the observation or later from photographs. We calculated the frequency of occurrence for each taxon of the observed prey items.

\section{Blood sampling and corticosterone assay}

To assess the physiological condition of the birds, blood samples were collected and baseline corticosterone (CORT) levels were measured from birds with and without data loggers (see Table S4). Attachment of data loggers did not affect baseline corticosterone levels in a previous study (Takahashi et al. 2008). In cases where we had CORT data for both initial capture and recapture from the same bird, we used the average CORT value. Blood collection and handling procedures followed those described in Kitaysky et al. (1999) and Benowitz-Fredericks et al. (2008). In brief, all samples for baseline CORT were collected within 3 min of capture. Plasma samples were frozen at $-20^{\circ} \mathrm{C}$ and transported to the University of Alaska Fairbanks for analysis. Plasma CORT levels were measured in duplicate for each sample after extraction with redistilled dichloromethane using radioimmunoassay (for detailed methods see Kitaysky et al. 1999). Before extraction, tritiated CORT (2000 counts per minute [cpm]) was added to each plasma sample to control for loss of CORT during extraction. Recovery values ranged from 80 to $99 \%$ and were used to adjust assayed concentrations of CORT. Coefficient of variation (CV) for inter- and intra-assay were less than 4 and $2 \%$, respectively. 


\section{Environmental data and GIS analyses}

The bathymetry where the dives occurred was investigated using ArcGIS $^{\circledR}$ v.10.3 (ESRI) with digital bathymetric data (Etopo 1, provided by NOAA National Centers for Environmental Information). Areas with bottom depth shallower than 200 m were defined as on-shelf (Paredes et al. 2015), and other areas (bottom depth $>200 \mathrm{~m}$ ) were defined as offshelf. We categorized each dive into on- or off-shelf dives based on the bathymetry of the dive location. We categorized foraging trips into on- or off-shelf trips based on the location of the dive that was most distant from the colony in the focal foraging trip.

Bottom temperature data from the Eastern Bering Sea Continental Shelf Survey of NOAA Alaska Fisheries Science Center (www.afsc.noaa.gov/RACE/ groundfish/survey_data/ebswater.htm) were used to assess the summer oceanographic conditions around Pribilof Islands for each year. The average summer bottom temperature within a $150 \mathrm{~km}$ radius of the Pribilof Islands trawl survey was calculated for each year. We also examined the southern extent of the cold pool (where bottom temperature $<2^{\circ} \mathrm{C}$ ), by spatially interpolating the bottom temperature data by the kriging function of ArcGIS ${ }^{\circledR}$. Based on bottom temperature (see Table S1), we considered 2003 to 2005 and 2014 to 2015 as warm years, 2006 as an intermediate year, and 2007 to 2013 as cold years - which are in accordance with warm versus cold classifications based on the timing of winter ice retreat (Ice Retreat Index in Zador 2015), or a combination of several oceanographic parameters (Will \& Kitaysky 2018, this Theme Section).

\section{Statistics}

We examined the effect of summer bottom temperature on foraging parameters and nutritional stress levels with linear mixed models (LMM). For the models of foraging trip parameters, where multiple values were obtained per bird, we set annual mean summer bottom temperature as a continuous fixed factor, sex and trip type (overnight or day trips) as categorical fixed factors, and year and bird ID as random factors. For the models of dive depth, where multiple values were obtained per bird, we set annual mean summer bottom temperature as a continuous fixed factor, sex as a categorical fixed factor, and year and bird ID as random factors. For the models of daily total dive time, proportion of night dives, and baseline corticosterone levels, where a single value was obtained for each individual, we set annual mean summer bottom temperature as a continuous fixed factor, sex as a categorical fixed factor, and year as a random factor. We used the 'lme4' and 'multcomp' packages in R v.23.1.1 software (R Core Team 2014). We examined the effect of summer bottom temperature on the frequency of occurrence of prey items in chick diet by calculating Pearson correlation coefficients. Data are presented as mean values \pm SD, unless stated otherwise.

\section{RESULTS}

\section{Foraging location and distance}

Data on foraging locations were available for a total of 67 trips from 54 birds deployed with GPS over 4 cold (2008, 2009, 2010, 2013) and 2 warm (2014, 2015) years. Murres foraged on the continental shelf regions near the breeding colony during day foraging trips in both cold and warm years (Fig. 1A,B). In contrast, murres tended to forage to the south of the colony, in both on-shelf and off-shelf habitats, during overnight foraging trips in cold years (Fig. 1C, Table S1). Murres tended to forage to the north of the colony, in on-shelf regions, during overnight foraging trips in warm years (Fig. 1D, Table S1). Murres appeared to 'avoid' the cold bottom water (cold pool) located to the north of the colony in cold years, because a relatively low proportion of dives occurred in the regions of bottom temperature $<2{ }^{\circ} \mathrm{C}$ (Fig. 1A,C, Table S1).

The latitudinal positions of the foraging trips (at the most distant location from the colony) were positively related to summer bottom temperature for overnight foraging trips (Fig. 2A, Table 1). Day foraging trips had smaller foraging ranges $(20.5 \pm 11.2 \mathrm{~km}, \mathrm{n}=16$ trips) than overnight foraging trips $(67.3 \pm 44.6 \mathrm{~km}$, $\mathrm{n}=41$ trips). Foraging range did not relate to summer bottom temperature, after controlling for the effects of sex and trip types. (Table 1, Fig. 2B).

\section{Foraging trip duration}

Data on foraging trip durations were available for a total of 434 trips from 156 birds deployed with accelerometers, TDRs, or GPS over 9 yr. Foraging trip durations did not differ significantly among the type of devices where data on 2 types of devices were available (TDR vs. accelerometers in 2006 to 2007 and GPS vs. accelerometers in 2013 to 2015; LMM: effect of device type, estimate $=2.17 \pm 2.57$ and 0.26 
(A) Day trips
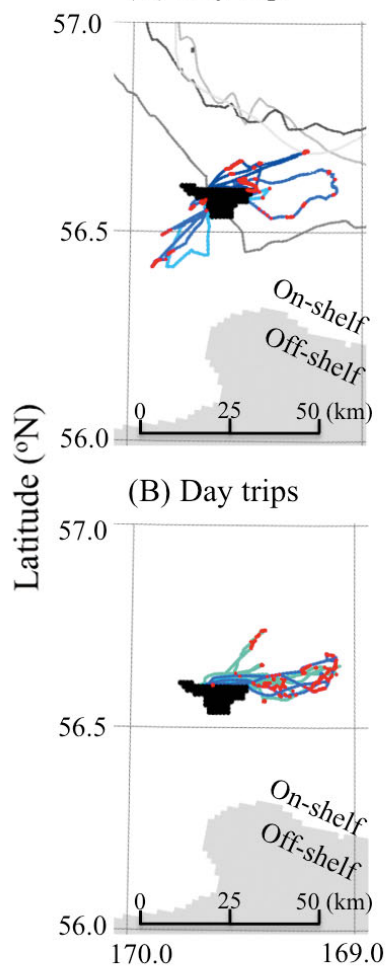

(C) Overnight trips

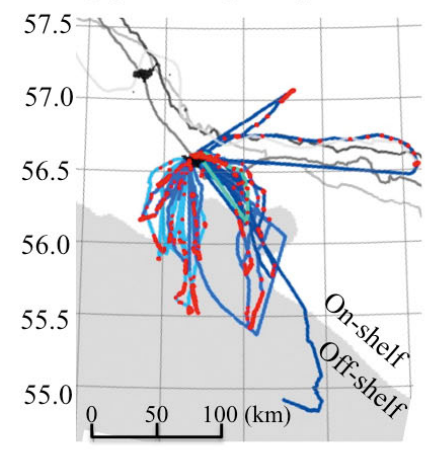

(D) Overnight trips

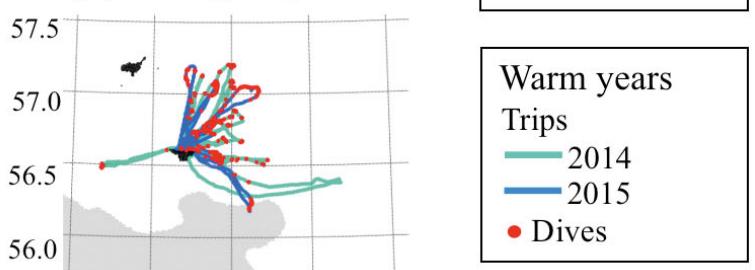

Longitude $\left({ }^{\circ} \mathrm{W}\right)$
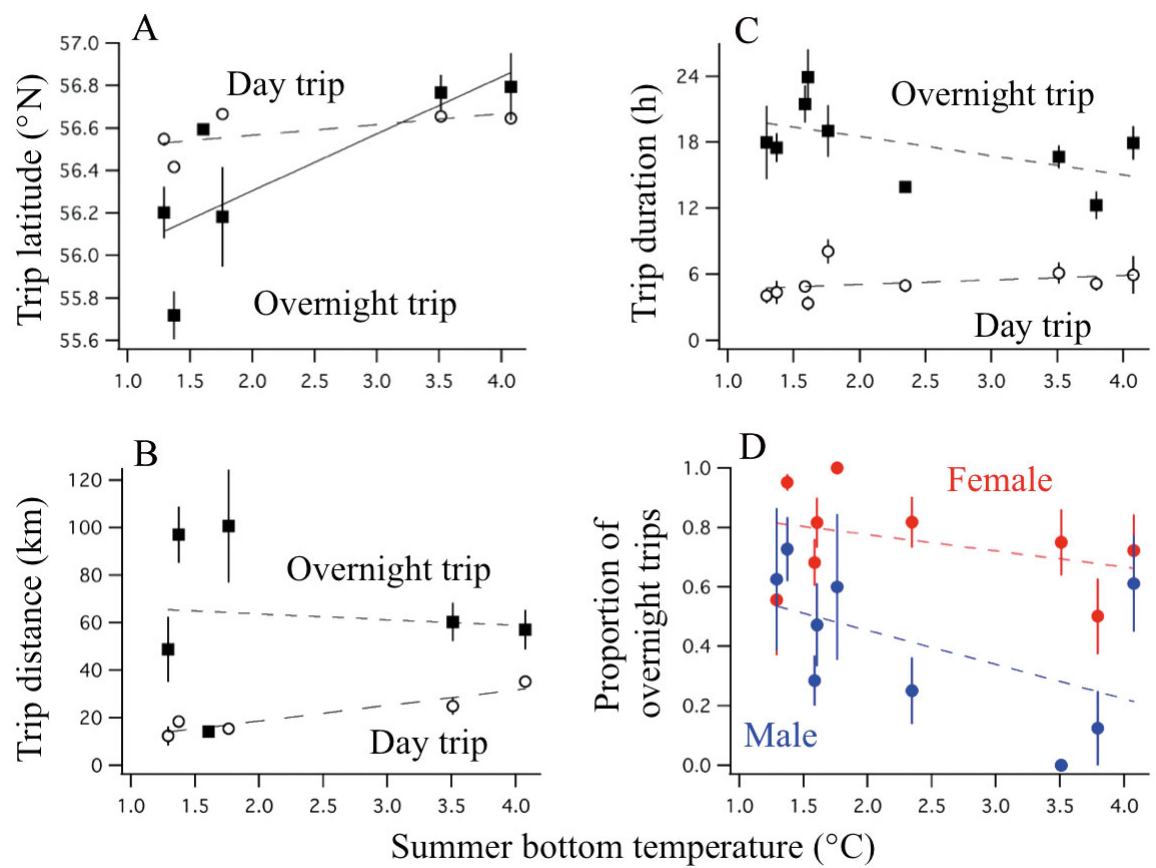

Fig. 1. Foraging tracks of thick-billed murres from St. George Island during $(\mathrm{A}, \mathrm{B})$ day trips and $(C, D)$ overnight trips in $(A, C)$ cold and $(\mathrm{B}, \mathrm{D})$ warm years. Tracks from different years are shown in different colors. For cold years, the southernmost extent of the cold pool (where bottom temperature $=2^{\circ} \mathrm{C}$ ) is also shown for each year

Summer bottom temperature $\left({ }^{\circ} \mathrm{C}\right)$

Fig. 2. Relationships between foraging trip parameters of thick-billed murres and summer bottom temperature. (A) Latitude of the most distant location from the colony, (B) maximum distance reached from the colony, and (C) foraging trip durations. Day and overnight foraging trips (trips ended before and after local midnight, respectively) are shown separately (open circles and closed squares). (D) Proportion of overnight trips of all trips in males (blue) and females (red). Annual mean and SE values are shown with a simple regression line. Solid lines: statistically significant relationships; dashed lines: non-significant relationships. Statistical analyses were conducted with linear mixed effect models (see Table 1) $\pm 1.88, \mathrm{p}=0.49$ and 0.99 , respectively, with year and bird ID included as random factors). Therefore, we pooled the data on trip durations from accelerometers, TDRs, and GPS birds. Foraging trip durations were consistently shorter during the day than overnight foraging trips (Fig. 2C), and were shorter for females than males (Table 1). Trip duration did not relate to the summer bottom temperature, after controlling for the effects of sex and trip types (Table 1, Fig. 2C). Proportion of overnight foraging 


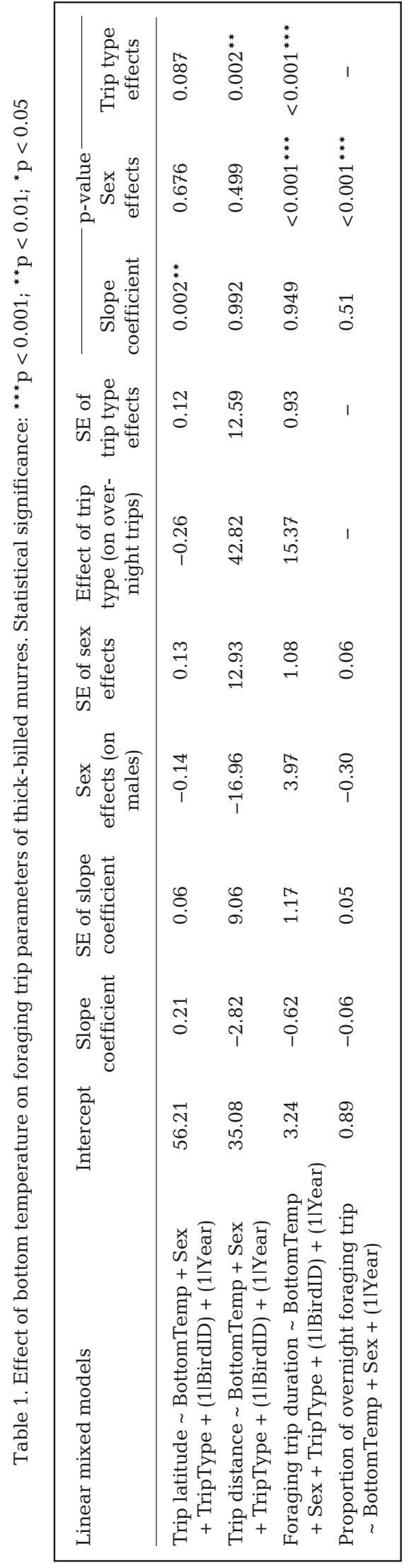

trips in all trips were higher for females than males (Table 1), but did not relate to summer bottom temperature (Table 1, Fig. 2D).

\section{Diving behavior}

Data on diving behavior were available for a total of 156 birds deployed with accelerometer, GPS-TDRs or TDRs over the $9 \mathrm{yr}$ (Table S1). Maximum dive depths showed clear diel patterns in all years, being shallower at night and deeper during the day as previously shown (Takahashi et al. 2008, Paredes et al. 2015, Young et al. 2015). During nighttime (time between sunset and sunrise), maximum dive depths were deeper in years of higher summer bottom temperature (Table 2, Fig. 3A). During the middle of the day ( $6 \mathrm{~h}$ period spanning local midday), maximum dive depths were shallower in years when higher proportions of pollock occurred in chick diets (Table 2, Fig. 3B; see below for chick diet results), and were not related to summer bottom temperatures (Table 2). Total time spent diving ( $\geq 5 \mathrm{~m}$ depth) per day was higher in years of lower summer bottom temperature, suggesting that total diving effort of murres increased in cold years (Table 2, Fig. 3C). The proportion of nighttime dives differed between males and females, and was lower in years of higher summer bottom temperature for males, but did not change for females (Table 2, Fig. 3D).

\section{Chick diet}

A total of 621 chick meals delivered by parents were observed over the $9 \mathrm{yr}$. Juvenile walleye pollock, Pacific sandlance, benthic fishes (including prickleback, sculpin, flatfish, and others listed in Table S3), and cephalopods were the major prey items during 2004 to 2015 (Table S3). Frequency of occurrence of cephalopods and benthic fishes in chick meals correlated negatively with summer bottom temperature (Pearson's $\mathrm{r}=-0.849, \mathrm{p}=0.004$, and $\mathrm{r}=-0.843, \mathrm{p}=0.004$, respectively, $\mathrm{n}=9 \mathrm{yr}$ ), whereas that of walleye pollock correlated positively with summer bottom temperature $(\mathrm{r}=0.759, \mathrm{p}=0.018$; Fig. 4).

\section{Baseline corticosterone}

Data on baseline corticosterone samples were available for a total of 509 birds for 10 yr during 2003 
Table 2. Effect of bottom temperature and diet on diving behaviors of thick-billed murres. Statistical significance: ${ }^{* * *} \mathrm{p}<0.001 ;{ }^{* *} \mathrm{p}<0.01 ;{ }^{*} \mathrm{p}<0.05$

\begin{tabular}{|c|c|c|c|c|c|c|c|c|}
\hline \multirow[t]{2}{*}{ Linear mixed models } & \multirow{2}{*}{ Intercept } & \multirow{2}{*}{$\begin{array}{c}\text { Slope } \\
\text { coeffi- } \\
\text { cient }\end{array}$} & \multirow{2}{*}{$\begin{array}{l}\text { SE of } \\
\text { slope co- } \\
\text { efficient }\end{array}$} & \multirow{2}{*}{$\begin{array}{c}\text { Sex } \\
\text { effects (on } \\
\text { males) }\end{array}$} & \multirow{2}{*}{$\begin{array}{c}\text { SE of } \\
\text { sex } \\
\text { effects }\end{array}$} & \multicolumn{2}{|c|}{$\longrightarrow p$-value } & \multirow[t]{2}{*}{ Interaction term } \\
\hline & & & & & & $\begin{array}{c}\text { Slope } \\
\text { coefficient }\end{array}$ & $\begin{array}{c}\text { Sex } \\
\text { effects }\end{array}$ & \\
\hline $\begin{array}{l}\text { Nighttime Depth BottomTemp } \\
+ \text { Sex + (1/BirdID) + (1/Year })\end{array}$ & 12.74 & 4.24 & 0.96 & -1.91 & 1.67 & $<0.001^{* * *}$ & 0.489 & Not significant \\
\hline $\begin{array}{l}\text { Midday Depth BottomTemp } \\
+ \text { Sex + (1/BirdID })+(1 / \text { Year })\end{array}$ & 61.11 & -4.63 & 3.08 & -4.30 & 3.31 & 0.285 & 0.397 & Not significant \\
\hline $\begin{array}{l}\text { Midday Depth } \sim \text { Proportion of Pollock } \\
\text { in diet }+ \text { Sex }+(1 \text { IBirdID })+(1 / \text { Year })\end{array}$ & 57.58 & -35.95 & 14.68 & -3.87 & 3.31 & $0.039^{*}$ & 0.509 & Not significant \\
\hline $\begin{array}{l}\text { Daily dive time } \sim \text { BottomTemp } \\
+ \text { Sex }+(1 / \text { Year })\end{array}$ & 3.19 & -0.30 & 0.12 & -0.11 & 0.17 & $0.037^{*}$ & 0.815 & Not significant \\
\hline $\begin{array}{l}\text { Proportion of night dives } \sim \\
\text { BottomTemp + Sex + (1/Year })\end{array}$ & 0.65 & -0.07 & 0.035 & -0.19 & 0.04 & 0.095 & $<0.001^{* * *}$ & $\begin{array}{l}\text { Marginally non- } \\
\text { significant }(p=0.077)\end{array}$ \\
\hline $\begin{array}{l}\text { Proportion of night dives } \\
\text { BottomTemp + (1/Year) (for male only) }\end{array}$ & 0.57 & -0.12 & 0.047 & - & - & $0.012^{*}$ & - & \\
\hline $\begin{array}{l}\text { Proportion of night dives } \sim \text { Bottom } \\
\text { Temp + (1/Year) (for female only) }\end{array}$ & 0.60 & -0.04 & 0.033 & - & - & 0.266 & - & \\
\hline
\end{tabular}

to 2015 (Table S4). Baseline corticosterone concentrations were lower in years of higher summer bottom temperature (Table 3, Fig. 5A). Data on both baseline corticosterone and diving behavior were available for 53 females and 34 males from $7 \mathrm{yr}$ (Table S4). The proportion of nighttime diving increased in birds with higher baseline corticosterone levels (Table 3, Fig. 5B), with a statistically significant increase in males $(p<0.001)$ and a marginal increase in females $(\mathrm{p}=0.0581)$.

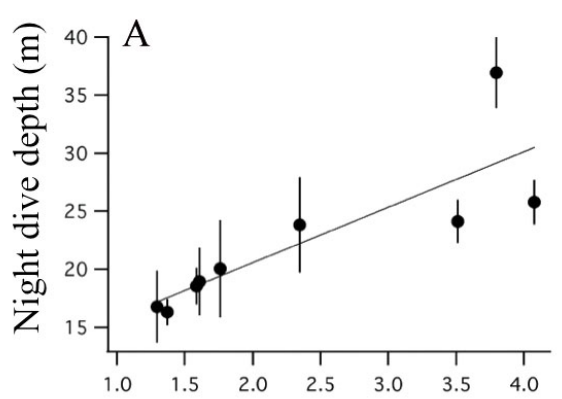

Summer bottom temperature $\left({ }^{\circ} \mathrm{C}\right)$

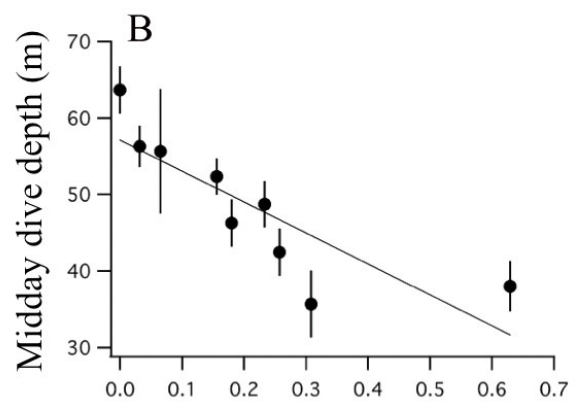

Proportion of pollock in chick diet

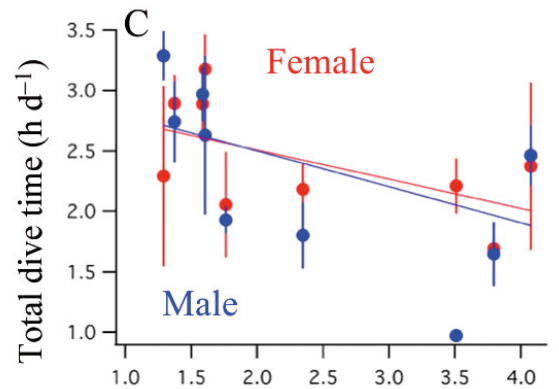

Summer bottom temperature $\left({ }^{\circ} \mathrm{C}\right)$

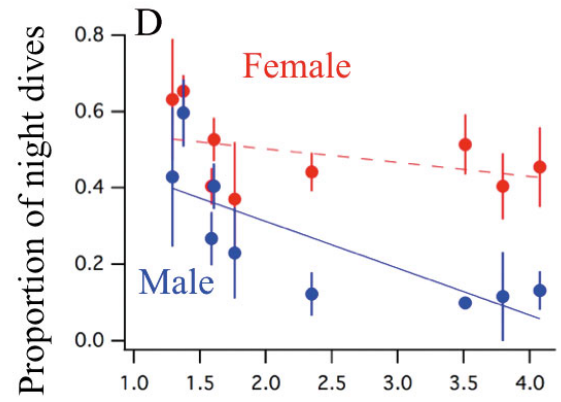

Summer bottom temperature $\left({ }^{\circ} \mathrm{C}\right)$

\section{DISCUSSION}

We examined foraging and physiological responses of breeding thick-billed murres to inter-annual climate variability in the continental shelf of the Bering Sea between 2003 and 2015. The southeastern Bering Sea shelf region experienced a prolonged 'warm' regime between 2000 and 2005, then a prolonged 'cold' regime between 2007 and 2013, and has returned to a 'warm' regime since
Fig. 3. Responses of diving parameters of thick-billed murres to $(A, C, D)$ summer bottom temperature or to (B) annual proportion of pollock in chick diet. Male and female values are shown separately for $(\mathrm{C})$ total dive time and (D) proportion of night dives. Grand mean and SE for the mean values of individual birds are shown with a simple regression line. Solid lines: statistically significant relationships; dashed lines: non-significant relationships. Statistical analyses were conducted with linear mixed effect models (see Table 2) 


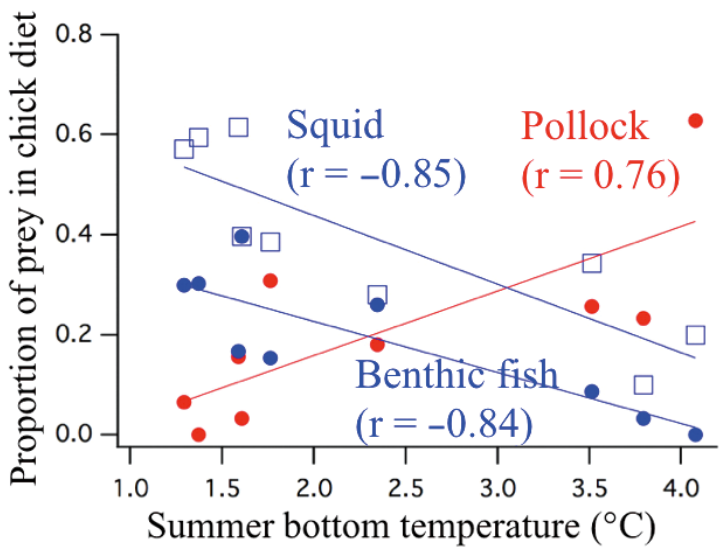

Fig. 4. Proportion of prey (frequency of occurrence) in thickbilled murre chick diets in relation to annual mean summer bottom temperature of the southeastern Bering Sea. Pearson correlation coefficient values are shown for each prey category. Statistical significance of regression lines as in Fig. 3

2014 (Zador 2015). Therefore, our dataset covered a wide range of oceanographic conditions. Our results were consistent with the hypothesis that warmer conditions increase the availability of juvenile walleye pollock on the shelf and have been beneficial for piscivorous seabirds breeding in the continental shelf regions of the southeastern Bering Sea.

\section{Foraging responses in warm and cold years}

In warm years, parent murres concentrated their foraging on the continental shelf during both day and overnight foraging trips, and delivered juvenile walleye pollock to their chicks more frequently (Figs. 1 \& 4). In warm years, which were usually associated with early ice retreat, age-0 pollock were distributed over the continental shelf and had 51 times higher near-surface density than in cold years (Renner et al. 2016, Hunt et al. 2017). We did not have information on the age of pollock delivered to chicks, but the pollock size was estimated in 2006 and 2007 relative to adult bill size (Ito 2011). The size of pollock ranged from 80 to $130 \mathrm{~mm}$, with the length of 100 to $110 \mathrm{~mm}$ observed most frequently (Ito 2011), which overlaps with the common sizes of age-0 fish (Brodeur \& Wilson 1996). Parent murres appeared to prey on

Table 3. Effect of bottom temperature on baseline corticosterone values, and on the effect of baseline corticosterone on proportion of nighttime dives in thick-billed murres. Statistical significance: ${ }^{* * *} \mathrm{p}<0.001 ;{ }^{* *} \mathrm{p}<0.01 ;{ }^{*} \mathrm{p}<0.05$

\begin{tabular}{|c|c|c|c|c|c|c|c|c|}
\hline \multirow[t]{2}{*}{ Linear mixed models } & \multirow[t]{2}{*}{ Intercept } & \multirow{2}{*}{$\begin{array}{c}\text { Slope } \\
\text { coeffi- } \\
\text { cient }\end{array}$} & \multirow{2}{*}{$\begin{array}{c}\text { SE of } \\
\text { slope co- } \\
\text { efficient }\end{array}$} & \multirow{2}{*}{$\begin{array}{l}\text { Sex } \\
\text { effects (on } \\
\text { males) }\end{array}$} & \multirow{2}{*}{$\begin{array}{l}\text { SE of } \\
\text { sex } \\
\text { effects }\end{array}$} & \multicolumn{2}{|c|}{ - p-value -} & \multirow[t]{2}{*}{ Interaction term } \\
\hline & & & & & & $\begin{array}{c}\text { Slope } \\
\text { coefficient }\end{array}$ & $\begin{array}{l}\text { Sex } \\
\text { effects }\end{array}$ & \\
\hline LogCORT $\sim$ BottomTemp + (1/Year) & 0.85 & -0.09 & 0.03 & - & - & $0.010^{*}$ & - & \\
\hline $\begin{array}{l}\text { Proportion of night dives } \\
\text { logCORT+ Sex+ (1IYear) }\end{array}$ & 0.24 & 0.41 & 0.08 & -0.16 & 0.05 & $<0.001^{* * *}$ & $0.002^{* *}$ & $\begin{array}{l}\text { Marginally non- } \\
\text { significant }(p=0.074)\end{array}$ \\
\hline $\begin{array}{l}\text { Proportion of night dives } \\
\text { logCORT+ (1IYear) (for male only) }\end{array}$ & -0.03 & 0.59 & 0.10 & - & - & $<0.001^{* * *}$ & - & \\
\hline $\begin{array}{l}\text { Proportion of night dives } \\
\text { logCORT+ (1IYear) (for female only) }\end{array}$ & 0.38 & 0.23 & 0.11 & - & - & 0.058 & - & \\
\hline
\end{tabular}

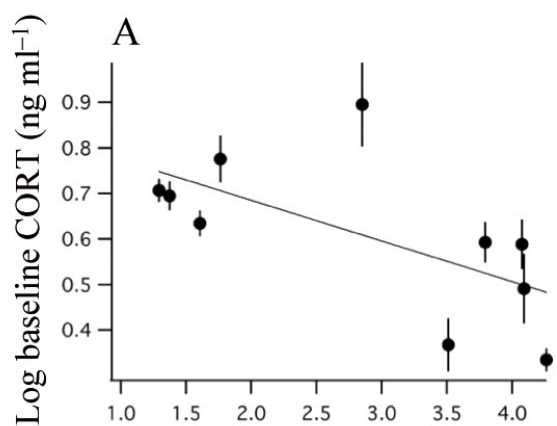

Summer bottom temperature $\left({ }^{\circ} \mathrm{C}\right)$

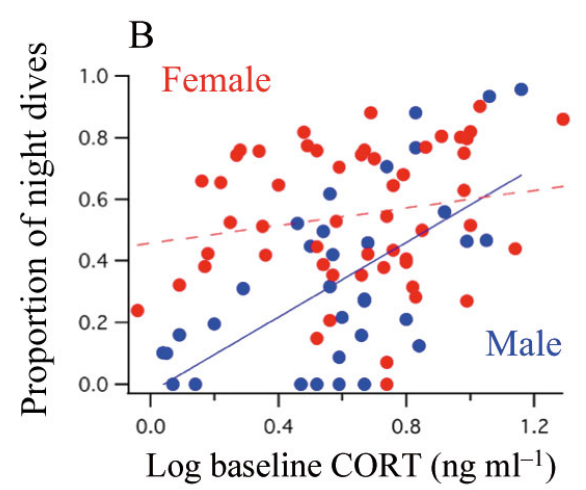

Fig. 5. (A) Relationship between thick-billed murre baseline corticosterone (CORT) levels and summer bottom temperature over $10 \mathrm{yr}$ during 2003 to 2015. Annual mean and $\mathrm{SE}$ values are shown with a simple regression line. (B) Relationship between proportion of night dives and baseline CORT in males (blue: $\mathrm{n}=34$ birds) and females (red: $\mathrm{n}=53$ birds). Data points indicate individual birds. See Table 3 for linear mixed model statistics. Statistical significance of regression lines as in Fig. 3 
juvenile pollock, not only for chick provisioning but also for self-feeding during warm years. Video records from bird-borne cameras showed that murres frequently fed on juvenile pollock in 2014, a warm year (Sato et al. 2015). Otoliths of juvenile pollock were also found in samples of stomach lavage (Ito 2011, Paredes et al. 2015). In 2004, another warm year, murres concentrated their dives at depths just below the thermocline (20 to $40 \mathrm{~m}$ depths; Takahashi et al. 2008), where schools of juvenile pollock have been observed (Brodeur 1998). We found that murres dove shallower during midday in years with a high proportion of juvenile pollock in chick diets, suggesting they relied on this abundant prey aggregated at shallow depths over the continental shelf in warm years. Also, because murres spent less time diving per day (Fig. 3C) and showed lower baseline corticosterone concentrations in warm years (Fig. 5A), we suggest that feeding on nearby juvenile pollock in warm years is beneficial for parent murres. Although age0 pollock were reported to have lower energy density in warm years than cold years (Heintz et al. 2013), we presume that the benefit of higher abundance and accessibility of age- 0 pollock outweighed the disadvantage of lower prey quality for parent murres in warm years.

In cold years, during overnight trips, murres tended to target off-shelf regions south of St. George Island, and dove in both on-shelf and off-shelf habitats (Fig. 1). In on-shelf habitats, they made relatively fewer dives in the area of the cold pool (bottom temperature $<2^{\circ} \mathrm{C}$ ) (Fig. 1C). Male murres increased the proportion of night dives, and nighttime dives were shallower for both sexes in cold years (Table 1, Fig. 3A,D). In cold years, the biomass of euphausiids was elevated in shelf break regions (175 to $200 \mathrm{~m}$ water depth; Hunt et al. 2017). Euphausiids were not found in chick diets, but were found in the stomach contents of adults (Ito 2011, Paredes et al. 2015). Our results show that squid dominated chick diets in cold years (Fig. 4), and a previous study reported that squid beaks occurred in $>60 \%$ of stomach contents of adult birds from St. George Island in cold years (Paredes et al. 2015). These results suggest that murres feed on prey such as euphausiids or squids which might be more readily available in shelf break and off-shelf regions at night due to their diel vertical migration behavior and/or advection to ocean surface by upwelling (Schabetsberger et al. 2000, Nishikawa et al. 2001). In contrast to overnight trips, murres remained in the on-shelf habitat during day trips (Fig. 1). They tended to dive deeper during the day in cold years, and delivered a higher proportion of benthic fish and squid to their offspring. Harding et al. (2013) and Paredes et al. (2015) suggested that prey species available in the off-shelf ocean basin habitat might be of higher quality than those available on the shelf in cold years, and proximity to off-shelf habitat might buffer against food shortages on the continental shelf (Paredes et al. 2012). Our nutritional stress results suggest that on-shelf foraging on juvenile pollock in warm years was more beneficial than combined on-shelf and off-shelf foraging for other prey in cold years.

\section{Constraints on foraging responses}

Central place foraging from a breeding colony might constrain the ability of parent murres to change the duration and distance of their foraging trips. This appears to be the case for day trips, as murres kept foraging on the shelf and had similar foraging trip durations in warm and cold years, presumably to maintain chick-provisioning rates. However, in cold years, benthic fishes made up a greater proportion of chick diets (Fig. 4), which were presumably obtained during deep daytime dives reaching to or near the sea floor. Paredes et al. (2015) reported that flatfish were offered by parents, but often chicks were not able to swallow these prey. Thus, murres might need to rely on suboptimal prey for chick-provisioning in cold years, due to a restricted foraging range of day trips $(20 \mathrm{~km}$ from breeding colony, on average). Sex differences in reproductive duties might also constrain the foraging of male murres. For murres breeding at a relatively low-latitudes like St. George Island, chick fledging occurs at night and male parents accompany their fledglings. Therefore, males usually attend nests at night and forage during the day (Paredes et al. 2008, but see also Elliott et al. 2010). This appeared to be the case in our study, based on the lower proportion of overnight foraging trips and night dives by males compared to females (Figs. 2D \& 3D). In cold years, however, males increased nighttime foraging, presumably because they experienced difficult self-feeding conditions (as suggested by elevated corticosterone levels) during the daytime (Fig. 5B). A strong positive relationship between corticosterone levels and the proportion of nighttime diving supports this argument. We suggest that sexual differences in reproductive duties might affect an individual's response to inter-annual changes in foraging conditions. 


\section{Possible confounding factors}

We need to consider potential confounding factors when interpreting our results. First, the type and size of data loggers used were different among study years. Nevertheless, we used accelerometers and TDRs during 2006 and 2007, and accelerometers and GPS loggers from 2013 to 2015, and found that foraging trip durations did not differ among device types (see 'Results'). We thus were able to pool the foraging trip durations from 2 types of devices. Second, the attachment of data loggers might influence the behavior of the birds. Ito (2011) and Paredes et al. (2015) compared the foraging trip durations and chick feeding rates of 'loggered' birds with those of control birds from 2006 to 2009. Foraging trip durations and chick feeding rates of birds carrying loggers were longer and lower than those of control birds in 1 of 4 years (in 2006 for trip duration and in 2009 for chick feeding rates). Although we cannot dismiss the effect of data logger attachment, we believe that the behavior of the birds was not radically modified and our betweenyear comparisons of foraging behavior of birds with data loggers were reasonably representative. Third, our deployment sites on the island were not always the same between different years, which might confound annual changes in the foraging locations (e.g. Soanes et al. 2014). We used study sites at the northern side of the island in most years, but also used sites on the southern side of the colony in 2009, one of the cold years. However, our results on the shift of foraging locations toward off-shelf regions in cold years were consistent, even if we restricted our dataset to foraging tracks from only the northern side of the island (see Fig. S1 in the Supplement).

\section{Implications}

Our results on the shifts of foraging locations of murres toward the continental shelf in warm years and toward shelf break and off-shelf habitats in cold years are consistent with the results of other studies comparing the distribution and diet of seabirds in the southeastern Bering Sea. Renner et al. (2016) and Hunt et al. (2017) reported that thick-billed murres were observed in shallower waters in early-iceretreat (typically warm) compared to late-ice-retreat (typically cold) years. Stable isotope analysis of blood tissues suggested that thick-billed murres relied more on shelf-based prey in warm years than in cold years (Will \& Kitaysky 2017). Thus, our results on the foraging responses of thick-billed murres to ocean

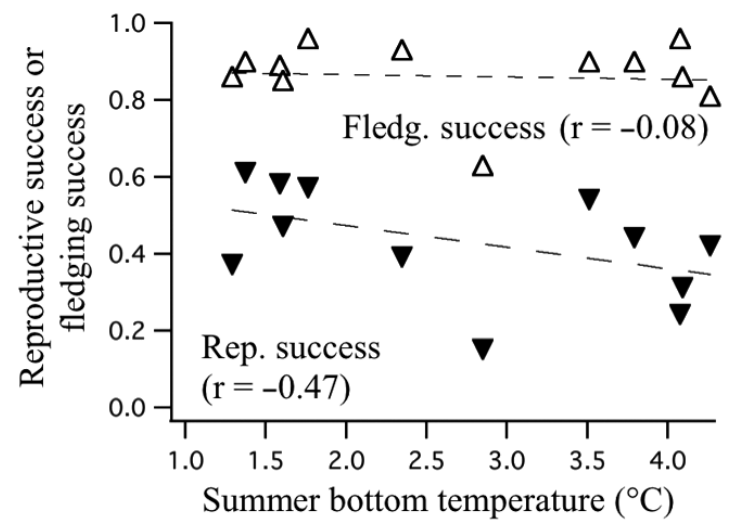

Fig. 6. Reproductive success $(\boldsymbol{\nabla})$ and fledging success $(\Delta)$ of thick-billed murres at St. George Island in relation to summer bottom temperature between 2003 and 2015. Reproductive success (number of chicks fledged/number of nests with eggs) and fledging success (number of chicks fledged/ number of nests with chicks hatched) were based on biological monitoring study by US Fish and Wildlife Service and were extracted from Tappa et al. (2015, their Table 23). No significant effects of summer bottom temperature were detected (Pearson correlation coefficient: $r=-0.47, p=0.12$ for reproductive success; $r=-0.08, p=0.80$ for fledging success)

conditions appear to be robust, and may apply to other piscivorous seabirds such as black-legged kittiwakes and common murres Uria aalge (Paredes et al. 2014, Will \& Kitaysky 2017).

The breeding population of thick-billed murres at St. George Island appeared to increase from the mid1980 s to $1999-2002$, and then remained relatively stable during 2002 to 2014 (Tappa et al. 2015). Reproductive parameters of thick-billed murres did not show any clear responses to climate conditions in a previous study (Renner et al. 2014). Indeed, reproductive and fledging success were relatively stable over a range of warm and cold conditions during our study period (Tappa et al. 2015, our Fig. 6), which was in contrast to the clear responses we observed in the behavioral and physiological parameters. This suggests that murres buffer the effect of inter-annual climate variability on reproductive parameters via changes in their fine-scale foraging behavior. Such 'behavioral buffering' has been documented in various seabird species, and appears to be a common response to changes in foraging conditions (Harding et al. 2007, Grémillet et al. 2012, Einoder et al. 2013). However, our concurrent corticosterone data suggest that there may be some associated costs to parents of this behavioral buffering. We suggest that a combined study of seabird foraging behavior and physiological stress is an effective integrative approach to examining the impact of environmental changes on 
breeding seabirds (Piatt et al. 2007, Kitaysky et al. 2007, 2010, Satterthwaite et al. 2012).

Our results showed that thick-billed murres decreased foraging effort and incurred less nutritional stress in warm years, indicating that warming conditions are currently beneficial due to the availability of juvenile pollock on the continental shelf. Warming conditions appear to benefit black-legged kittiwakes in the southeastern Bering Sea (Satterthwaite et al. 2012), which, combined with our results, suggest that the availability of forage fish on the continental shelf increased from surface strata to the mid-water column in warm years. However, this pattern may be specific to the continental shelf regions of the southeastern Bering Sea that experience seasonal ice cover. On Bogoslof Island, Aleutian Islands, where murres rely on ocean basin habitat for foraging, common and thick-billed murres incurred less nutritional stress in cold years (Barger \& Kitaysky 2012), which is in contrast to our results. This suggest that a better understanding of region-specific ecological processes (on-shelf availability of pollock in warm years, in our case) are needed to fully assess the impact of ocean climate changes on the southeastern Bering Sea ecosystems. Moreover, studies suggest that recruitment of age- 0 pollock to age-1 was lower in warm years on the continental shelf due to poor body condition of juvenile pollock in the fall (Mueter et al. 2011, Heintz et al. 2013) and increased mortality due to predation and/or cannibalism (Coyle et al. 2011). In addition, oscillations of warm and cold oceanographic conditions between years may be a prerequisite to support the high productivity of this ice-influenced continental shelf ecosystem (Hunt et al. 2011). Whether continued warming of the southeastern Bering Sea would be beneficial or detrimental to piscivorous seabirds breeding on the continental shelf needs further investigation.

Acknowledgements. We are indebted to all team members for their assistance in all aspects of our fieldwork on St. George Island, especially the staff of Alaska Maritime National Wildlife Refuge (AMNWR), US Fish and Wildlife Service (USFWS). The St. George Traditional Council and St. George Island Institute also provided logistical support to the field team. We thank Nora Rojek and Heather Renner, AMNWR, USFWS, for providing archived chick diet data for 2008 to 2010 collected as part of NPRB project B63. Keiichi Fukaya of the Institute of Statistical Mathematics, Japan, gave invaluable advice on the statistical analyses. Heather Renner and Andrew Constable provided thoughtful comments on the manuscript. The fieldwork during 2004 to 2007 and 2013 to 2015, and data analyses were supported by the Green Network of Excellence Program (GRENE) Arctic Climate Change Research Project and Arctic Challenge for Sustainability (ArCS) Project of the Ministry of Education,
Culture, Sports, Science and Technology in Japan, and JSPS Kakenhi grant 1164062, 115255003, $15 \mathrm{H} 02857$ and 16H02705. The fieldwork during 2008 to 2010 was supported by the Bering Sea Integrated Ecosystem program funded by the North Pacific Research Board and the National Science Foundation (project B63 and B77 to D. B. Irons and D. D. Roby, project B77 to A.S.K.) and by AMNWR, USFWS. The publication is contribution No. 183 of the BEST-BSIERP Bering Sea Project and No. 651 of the North Pacific Research Board. The production of this paper was supported by an NIPR publication subsidy. This work has been performed under all required USA Federal, State and special use permits, and bird capture and methods of logger attachment were approved by the Institutional Animal Care and Use Committee of the University of Alaska Fairbanks.

\section{LITERATURE CITED}

Aydin K, Mueter F (2007) The Bering Sea - a dynamic food web perspective. Deep Sea Res II 54:2501-2525

Barger CP, Kitaysky AS (2012) Isotopic segregation between sympatric seabird species increase with nutritional stress. Biol Lett 8:442-445

* Barrett RT, Erikstad KE, Sandvik H, Myksvoll M and others (2015) The stress hormone corticosterone in a marine top predator reflects short-term changes in food availability. Ecol Evol 5:1306-1317

Benowitz-Fredericks ZM, Shultz MT, Kitaysky AS (2008) Stress hormones suggest opposite trends of food availability for planktivorous and piscivorous seabirds in 2 years. Deep Sea Res II 55:1868-1876

Bost CA, Cotté C, Terray P, Barbraud C and others (2015) Large-scale climatic anomalies affect marine predator foraging behaviour and demography. Nat Commun 6: 8220

Brodeur RD (1998) In situ observations of the association between juvenile fishes and scyphomedusae in the Bering Sea. Mar Ecol Prog Ser 163:11-20

* Brodeur RD, Wilson MT (1996) A review of the distribution, ecology and population dynamics of age-0 pollock in the Gulf of Alaska. Fish Oceanogr 5(Suppl 1):148-166

Brodeur RD, Wilson MT, Walters GE, Melnikov IV (1999) Forage fishes in the Bering Sea: distribution, species associations, and biomass trends. In: Loughlin TR, Ohtani K (eds) Dynamics of the Bering Sea. AK-SG-9903, University of Alaska Sea Grant, Fairbanks, AK, p 509-536

Cairns DK (1987) Seabirds as indicators of marine food supplies. Biol Oceanogr 5:261-271

Coyle KO, Eisner LB, Mueter FJ, Pinchuk AI and others (2011) Climate change in the southeastern Bering Sea: impacts on pollock stocks and implications for the oscillating control hypothesis. Fish Oceanogr 20:139-156

Finoder LD, Page B, Goldsworthy SD (2013) Feeding strategies of the short-tailed shearwater vary by year and seasurface temperature but do not affect breeding success. Condor 115:777-787

*Eisner LB, Napp JM, Mier KL, Pinchuk AI, Andrews AG (2014) Climate-mediated changes in zooplankton community structure for the eastern Bering Sea. Deep Sea Res II 109:157-171

Felliott KH, Gaston AJ, Crump D (2010) Sex-specific behavior by a monomorphic seabird represents risk partitioning. Behav Ecol 21:1024-1032 
Elliott KH, Ricklefs RE, Gaston AJ, Hatch SA, Speakman JR, Davoren GK (2013) High flight costs, but low dive costs, in auks support the biomechanical hypothesis for flightlessness in penguins. Proc Natl Acad Sci USA 110: 9380-9384

Gaston AJ, Woo K, Hipfner JM (2003) Trends in forage fish populations in northern Hudson Bay since 1981, as determined from the diet of nestling thick-billed murres Uria lomvia. Arctic 58:227-233

Grémillet D, Welcker J, Karnovsky NJ, Walkusz W and others (2012) Little auks buffer the impact of current Arctic climate change. Mar Ecol Prog Ser 454:197-206

Griffiths R, Double MC, Orr K, Dawson RJG (1998) A DNA test to sex most birds. Mol Ecol 7:1071-1075

Harding AMA, Piatt JF, Schmutz JA, Shultz MT, Pelt TIV, Kettle AB, Speckman SG (2007) Prey density and the behavioral flexibility of a marine predator: the common murre (Uria aalge). Ecology 88:2024-2033

Harding A, Paredes R, Suryan R, Roby D and others (2013) Does location really matter? An inter-colony comparison of seabirds breeding at varying distances from productive oceanographic features in the Bering Sea. Deep Sea Res II 94:178-191

Heintz RA, Siddon EC, Farley EV, Napp JM (2013) Correlation between recruitment and fall condition of age- 0 pollock (Theragra chalcogramma) from the eastern Bering Sea under varying climate conditions. Deep Sea Res II 94:150-156

Hollowed AB, Barbeaux SJ, Cokelet ED, Farley E and others (2012) Effects of climate variations on pelagic ocean habitats and their role in structuring forage fish distributions in the Bering Sea. Deep Sea Res II 65-70:230-250

Hunt GL, Coyle KO, Eisner LB, Farley EV and others (2011) Climate impacts on eastern Bering Sea foodwebs: a synthesis of new data and an assessment of the Oscillating Control Hypothesis. ICES J Mar Sci 68:1230-1243

Hunt GL, Renner M, Kuletz KJ, Salo S and others (2018) Timing of sea-ice-retreat affects the distribution of seabirds and their prey in the southeastern Bering Sea. Mar Ecol Prog Ser 593:209-230

Ito $M$ (2011) Prey selection and foraging behavior during self-feeding and chick-provisioning in seabirds: foraging strategy differences among the single and multiple preyloaders. PhD thesis, Hokkaido University

Ito M, Takahashi A, Kokubun N, Kitaysky AS, Watanuki Y (2010) Foraging behavior of incubating and chick-rearing thick-billed murres Uria lomvia. Aquat Biol 8: 279-287

Jenouvrier S (2013) Impacts of climate change on avian populations. Glob Change Biol 19:2036-2057

Kitaysky AS, Wingfield JC, Piatt JF (1999) Dynamics of food availability, body condition and physiological stress response in breeding black-legged kittiwakes. Funct Ecol 13:577-584

Kitaysky AS, Hunt GL, Flint EN, Rubega MA, Decker MB (2000) Resource allocation in breeding seabirds: responses to fluctuations in their food supply. Mar Ecol Prog Ser 206:283-296

Kitaysky AS, Piatt JF, Wingfield JC (2007) Stress hormones link food availability and population processes in seabirds. Mar Ecol Prog Ser 352:245-258

Kitaysky AS, Piatt JF, Hatch SA, Kitaiskaia EV, BenowitzFredericks ZM, Shultz MT, Wingfield JC (2010) Food availability and population processes: severity of nutritional stress during reproduction predicts survival of long-lived seabirds. Funct Ecol 24:625-637

Kokubun N, Takahashi A, Mori Y, Watanabe S, Shin HC (2010a) Comparison of diving behaviour and foraging habitat use between chinstrap and gentoo penguins breeding in the South Shetland Islands, Antarctica. Mar Biol 157:811-825

KKokubun N, Takahashi A, Ito M, Matsumoto K, Kitaysky AS, Watanuki Y (2010b) Annual variation in the foraging behaviour of thick-billed murres in relation to upperocean thermal structure around St. George Island, Bering Sea. Aquat Biol 8:289-298

KKokubun N, Yamamoto T, Sato N, Watanuki Y, Will A, Kitaysky AS, Takahashi A (2016) Foraging segregation of two congeneric diving seabird species (common and thick-billed murres) breeding on St. George Island, Bering Sea. Biogeosciences 13:2579-2591

* Mueter FJ, Litzow MA (2008) Sea ice retreat alters the biogeography of the Bering Sea continental shelf. Ecol Appl 18:309-320

* Mueter FJ, Bond NA, Ianelli JN, Hollowed AB (2011) Expected declines in recruitment of walleye pollock (Theragra chalcogramma) in the eastern Bering Sea under future climate change. ICES J Mar Sci 68: 1284-1296

* Nishikawa J, Nishida S, Moku M, Hidaka K, Kawaguchi K (2001) Biomass, abundance and vertical distribution of micronekton and large gelatinous zooplankton in the subarctic and the Bering Sea during the summer of 1997. J Oceanogr 57:361-375

* Paredes R, Jones IL, Boness DJ, Tremblay Y, Renner M (2008) Sex-specific differences in diving behaviour of two sympatric Alcini species: thick-billed murres and razorbills. Can J Zool 86:610-622

* Paredes R, Harding AMA, Irons DB, Roby DD and others (2012) Proximity to multiple foraging habitats enhances seabirds' resilience to local food shortages. Mar Ecol Prog Ser 471:253-269

*Paredes R, Orben RA, Suryan RM, Irons DB and others (2014) Foraging responses of black-legged kittiwakes to prolonged food-shortages around colonies on the Bering Sea shelf. PLOS ONE 9:e92520

* Paredes R, Orben RA, Roby DD, Irons DB and others (2015) Foraging ecology during nesting influences body size in a pursuit-diving seabird. Mar Ecol Prog Ser 533:261-276

* Piatt JF, Harding AMA, Shultz M, Speckman SG, van Pelt TI, Drew GS, Kettle AB (2007) Seabirds as indicators of marine food supplies: Cairns revisited. Mar Ecol Prog Ser 352:221-234

R Core Team (2014) R: a language and environment for statistical computing. R Foundation for Statistical Computing, Vienna

Renner HM, Mueter F, Drummond BA, Warzybok JA, Sinclair EH (2012) Patterns of change in diets of two piscivorous seabird species during 35 years in the Pribilof Islands. Deep Sea Res II 65-70:273-291

Renner HM, Drummond BA, Benson AM, Paredes R (2014) Reproductive success of kittiwakes and murres in sequential stages of the nesting period: relationships with diet and oceanography. Deep Sea Res II 109: 251-265

Kenner M, Salo S, Eisner LB, Ressler PH and others (2016) Timing of ice retreat alters seabird abundances and distributions in the southeast Bering Sea. Biol Lett 12: 20160276

* Riechert J, Becker PH, Chastel O (2014) Predicting repro- 
ductive success from hormone concentrations in the common tern (Sterna hirundo) while considering food abundance. Oecologia 176:715-727

Sato NN, Kokubun N, Yamamoto T, Watanuki Y, Kitaysky AS, Takahashi A (2015) The jellyfish buffet: jellyfish enhance seabird foraging opportunities by concentrating prey. Biol Lett 11:20150358

Satterthwaite WH, Kitaysky AS, Hatch SA, Piatt JF, Mangel $M$ (2010) Unifying quantitative life-history theory and field endocrinology to assess prudent parenthood in a long-lived seabird. Evol Ecol Res 12:779-792

Satterthwaite WH, Kitaysky AS, Mangel M (2012) Linking climate variability, productivity and stress to demography in a long-lived seabird. Mar Ecol Prog Ser 454:221-235

Schabetsberger R, Brodeur RD, Ciannelli L, Napp JM, Swartzman GL (2000) Diel vertical migration and interaction of zooplankton and juvenile walleye pollock (Theragra chalcogramma) at a frontal region near the Pribilof Islands, Bering Sea. ICES J Mar Sci 57:1283-1295

Siddon EC, Kristiansen T, Mueter FJ, Holsman KK, Heintz RA, Farley EV (2013) Spatial match-mismatch between juvenile fish and prey provides a mechanism for recruitment variability across contrasting climate conditions in the eastern Bering Sea. PLOS ONE 8:e84526

Sinclair EH, Vlietstral LS, Johnson DS, Zeppelin TK and others (2008) Patterns in prey use among fur seals and seabirds in the Pribilof Islands. Deep Sea Res II 55: 1897-1918

Soanes LM, Arnould JPY, Dodd SG, Milligan G, Green JA (2014) Factors affecting the foraging behaviour of the European shag: implications for seabird tracking studies. Mar Biol 161:1335-1348

Sorenson GH, Dey CJ, Madliger CL, Love OP (2017) Effectiveness of baseline corticosterone as a monitoring tool for fitness: a meta-analysis in seabirds. Oecologia 183: 353-365

Stabeno P, Kachel NB, Moore SE, Napp JM, Sigler M, Yamaguchi A, Zerbini AN (2012) Comparison of warm and cold years on the southeastern Bering Sea shelf and some implications for the ecosystem. Deep Sea Res II 65-70: 31-45

Editorial responsibility: Rory Wilson, Swansea, UK
Sydeman WJ, Thompson SA, Kitaysky A (2012) Seabirds and climate change: roadmap for the future. Mar Ecol Prog Ser 454:107-117

Takahashi A, Matsumoto K, Hunt GL Jr, Shultz MT and others (2008) Thick-billed murres use different diving behaviors in mixed and stratified waters. Deep Sea Res II 55:1837-1845

Tappa JD, Drummond BA, Romano MD (2015) Biological monitoring at St. George Island, Alaska, in 2015. Report AMNWR 2015/14, US Fish and Wildlife Service, Homer, AK

*Weimerskirch H, Louzao M, De Grissac S, Delord K (2012) Changes in wind pattern alter albatross distribution and life-history traits. Science 335:211-214

*Welcker J, Speakman JR, Elliott KH, Hatch SA, Kitaysky AS (2015) Resting and daily energy expenditures during reproduction are adjusted in opposite directions in freeliving birds. Funct Ecol 29:250-258

Will AP, Kitaysky AS (2018) Variability in trophic level and habitat use in response to environmental forcing: isotopic niche dynamics of breeding seabirds in the southeastern Bering Sea. Mar Ecol Prog Ser 593:247-260

Wyllie-Echeverria TINA, Wooster WS (1998) Year-to-year variations in Bering Sea ice cover and some consequences for fish distributions. Fish Oceanogr 7:159-170

Y Yamamoto T, Kokubun N, Kikuchi DM, Sato N and others (2016) Differential responses of seabirds to environmental variability over two years in the continental shelf and oceanic habitats of southeastern Bering Sea. Biogeosciences 12:17693-17720

* Young RC, Kitaysky AS, Barger CP, Dorresteijn I, Ito M, Watanuki Y (2015) Telomere length is a strong predictor of foraging behavior in a long-lived seabird. Ecosphere 6:art39

* Young RC, Barger CP, Dorresteijn I, Haussmann MF, Kitaysky AS (2016) Telomere length and environmental conditions predict stress levels but not parental investment in a long-lived seabird. Mar Ecol Prog Ser 556:251-259

Zador S (2015) Ecosystem considerations 2015: status of Alaska's marine ecosystems. North Pacific Fishery Management Council, Anchorage, AK

Submitted: June 29, 2017; Accepted: October 11, 2017 Proofs received from author(s): November 24, 2017 